\title{
Aboriginal Australian and Canadian First Nations Children's Literature
}

\author{
Angeline O'Neill \\ University of Notre Dame Australia
}

Follow this and additional works at: https://docs.lib.purdue.edu/clcweb

Part of the Comparative Literature Commons, and the Critical and Cultural Studies Commons

Dedicated to the dissemination of scholarly and professional information, Purdue University Press selects, develops, and distributes quality resources in several key subject areas for which its parent university is famous, including business, technology, health, veterinary medicine, and other selected disciplines in the humanities and sciences.

CLCWeb: Comparative Literature and Culture, the peer-reviewed, full-text, and open-access learned journal in the humanities and social sciences, publishes new scholarship following tenets of the discipline of comparative literature and the field of cultural studies designated as "comparative cultural studies." Publications in the journal are indexed in the Annual Bibliography of English Language and Literature (Chadwyck-Healey), the Arts and Humanities Citation Index (Thomson Reuters ISI), the Humanities Index (Wilson), Humanities International Complete (EBSCO), the International Bibliography of the Modern Language Association of America, and Scopus (Elsevier). The journal is affiliated with the Purdue University Press monograph series of Books in Comparative Cultural Studies. Contact: <clcweb@purdue.edu>

\section{Recommended Citation}

O'Neill, Angeline. "Aboriginal Australian and Canadian First Nations Children's Literature." CLCWeb: Comparative Literature and Culture 13.2 (2011): <https://doi.org/10.7771/1481-4374.1742>

This text has been double-blind peer reviewed by $2+1$ experts in the field.

The above text, published by Purdue University Press (CPurdue University, has been downloaded 1542 times as of 11/ $07 / 19$.

This document has been made available through Purdue e-Pubs, a service of the Purdue University Libraries. Please contact epubs@purdue.edu for additional information.

This is an Open Access journal. This means that it uses a funding model that does not charge readers or their institutions for access. Readers may freely read, download, copy, distribute, print, search, or link to the full texts of articles. This journal is covered under the CC BY-NC-ND license. 


\section{PURDUE}

UNIVERSITY PRESS <http://www.thepress.purdue.edu>

\section{CLCWeb: Comparative Literature and Culture}

ISSN 1481-4374 <http://docs.lib.purdue.edu/clcweb> Purdue University Press @Purdue University

CLCWeb: Comparative Literature and Culture, the peer-reviewed, full-text, and open-access learned journal in the humanities and social sciences, publishes new scholarship following tenets of the discipline of comparative literature and the field of cultural studies designated as "comparative cultural studies." In addition to the publication of articles, the journal publishes review articles of scholarly books and publishes research material in its Library Series. Publications in the journal are indexed in the Annual Bibliography of English Language and Literature (Chadwyck-Healey), the Arts and Humanities Citation Index (Thomson Reuters ISI), the Humanities Index (Wilson), Humanities International Complete (EBSCO), the International Bibliography of the Modern Langua-ge Association of America, and Scopus (Elsevier). The journal is affiliated with the Purdue University Press monog-raph series of Books in Comparative Cultural Studies. Contact: <clcweb@purdue.edu>

\section{Volume 13 Issue 2 (June 2011) Article 4 \\ Angeline O'Neill, \\ "Aboriginal Australian and Canadian First Nations Children's Literature"} <http://docs.lib.purdue.edu/clcweb/vol13/iss2/4>

Contents of CLCWeb: Comparative Literature and Culture 13.2 (2011)

Thematic issue About Indigenous Literatures

Ed. Angeline O'Neill and Albert Braz

<http://docs.lib.purdue.edu/clcweb/vol13/iss2/>

Abstract: In her article "Aboriginal Australian and Canadian First Nations Children's Literature" Angeline O'Neill discusses Canadian First Nations and Australian Aboriginal children's picture books and their appeal to a dual readership. Inuit traditional storyteller and writer Michael Kusugak, Nyoongar traditional storyteller and writer Lorna Little, and Wunambal elder Daisy Utemorrah are cases in point. Each appeals to Indigenous and non-Indigenous, child and adult readerships, thus challenging two assumptions in Western scholarship on literature that 1 ) the picture book genre is necessarily the domain of children and 2) that traditional Indigenous stories are, similarly, best suited to children. O'Neill considers the ways in which Indigenous children's picture books represent the interaction between text and culture and challenge notions of literariness. 


\section{Angeline O'NEILL}

\section{Aboriginal Australian and Canadian First Nations Children's Literature}

Children's literature is one of the most complex and challenging fields of literary studies. It is also one of the most underrated. Scholar and children's writer Peter Hunt has described it as "an amorphous, ambiguous creature; its relationship to its audience is difficult; its relationship to the rest of literature, problematic" (Literature 1). Scholars and critics of children's literature have certainly had to wrestle with fundamental issues of classification and evaluation. Yet as we know, it is one of the most powerful and, for some adults, even threatening forms of literature. After all, it is a very effective form of social engineering (e.g., on issues of racialization in children's literature see King and Streamas). If adults are to better understand the way it operates then it is apparent that we need to reconsider the processes of writing and reading, as Emer O'Sullivan, Peter Hunt, Clare Bradford, and Jon Stott, for example, have suggested. A further dimension is required when the text reaches across cultures (on characteristics of national narration in children's literature, see, e.g., Blažić). Of the multitude of subgenres collected together under the label of children's literature, from babies' concept books to formula fiction, I focus in my article on the Indigenous picture book genre as a problematic yet fruitful meeting place of oral and written traditions.

There exists a wide variety of picture books, some of which bear only a passing resemblance to each other. In the midst of them are the problematic picture books which defy easy categorization as they cater to both child and adult readers (on this, see, e.g., Wolf and DePasquale 88). Here we find an overlap with another burgeoning area, Indigenous literature. This all-too-general label includes a multitude of works from diverse genres for both adult and child readers. But, as the Chippewa writer Kateri Damm suggests, "any one solitary label distorts the multiplicity by suggesting that there is a cohesive, unitary basis of commonality among those so labelled" (13). Not surprisingly, Indigenous literature is an area which challenges such categorization (see Moses and Goldie xix-xxix; Harjo and Bird 19-31). My present discussion, however, is limited to children's picture books by Indigenous authors from Canada and Australia, whose aim is to educate the reader into the teller's own cultural experience (the distinction between lexical designations of the Indigenous population of Australia and Canada is of note: while the Indigenous peoples of Canada are acknowledged as First Nations, this is not yet so in Australia, where they continue to be "Aboriginal"). Inuit traditional storyteller and writer Michael Kusugak, Nyoongar traditional storyteller and writer Lorna Little, and Wunambal elder Daisy Utemorrah are cases in point. All appeal to Indigenous and non-Indigenous child and adult readerships and in this way challenge two often-held assumptions of Western literature: that the picture book genre is necessarily the domain of children and that traditional Indigenous stories are similarly best-suited to children. Indigenous children's picture books, it is thus assumed, must be a childish affair. Perhaps because many Indigenous writers seek to simplify aspects of their stories for young readers, too often the literary and socio-cultural value of their works goes unrecognized.

I postulate that a comparative methodology would be useful in this context as it enables a clearer view of the treatment by Indigenous and non-Indigenous writers, scholars and critics, and readers of Indigenous stories for children. Such a methodology brings into focus some of the unique features of Indigenous children's picture books, foremost among which is the integration of oral and written traditions. As O'Sullivan has noted, comparative literature is "situated on the interface between national philologies as well as between literary studies and such disciplines as philosophy, history of art, psychoanalysis, anthropology, sociology, film studies, theatre studies and so on" (5). Thus, I argue, it is in this space that the interaction of both adults and children with Indigenous children's picture books occurs. What, however, is children's literature? In An Introduction to Children's Literature, Hunt describes the field as "a remarkable area of writing ... one of the roots of Western culture" which involves and integrates words and pictures, overlapping other art forms and modes such as video and oral storytelling (1). While this is true, its existence and power are certainly not confined to Western culture. O'Sullivan deals with the issue more directly when she states that it is literature that "must adapt to the requirements and capabilities of its readers ... to bridge the communicatory distance between the unequal partners involved by adapting language, subject-matter and formal and thematic features to correspond to the children's stage of development and the repertory of skills they have already acquired" (14). Children's literature is also a form of social engineering driven by the asymmetry of communication between the adult 
writer and child reader, and the fact that all adults, having been conditioned themselves in a variety of ways, inevitably contribute towards the socio-cultural conditioning of children. This creates an interesting situation when the (adult) writer appeals either overtly or covertly in the picture book to an adult reader of another culture: the adult reader is often less open than the child reader to new ideas presented by the writer.

The picture book is the most easily recognizable form of children's literature and most often conforms to adult ideological expectations. Ideology is inscribed within the words, rule-systems and codes of every text and as we read "it reminds us of what is correct, commonsensical, or 'natural.' It tries, as it were, to guide both the writing and our subsequent readings of a text into coherence" (O'Sullivan 32). The genre of the picture book achieves this by integrating written and pictorial texts. It offers, potentially, an impressive meeting place for oral tradition and written tradition, and it is the genre of choice for an increasing number of Indigenous storytellers, many of whom are also writers of adult fiction (see Wolf and DePasquale 90). In the manner of oral storytelling, these texts often pose challenging questions to the alert adult reader. The problem is that as most adult Western readers come from a written tradition, they are unable or unwilling to engage with children's picture books in this way.

In a discussion of picture books and metafiction, David Lewis observes that "there is a tendency for us not to perceive picture books as unconventional and exceptional creations despite the fact that they frequently possess a playful and subversive quality" (132). Picture books are almost always associated with children, mainly because people believe children like and need pictures. While this may be true, studies have shown that children like and need pictures neither more nor less than adults. Similarly, it is a generalization that the imagination of children is qualitatively different from that of adults, who readily assume that visual images are "more concrete" than "abstract" words. So, the argument goes, pictures necessarily belong to children while words belong to maturity (Nodelman and Reimer 275). It is even sometimes extrapolated from this that written traditions are superior to oral traditions, a view which is convincingly dismissed by the Brazilian scholar Lynn Mario Menezes de Souza. Menezes de Souza's work focuses on Indigenous writing in Amazonian Brazil and on the relationship between Indigenous knowledge and writing. Ignorance of Indigenous culture and language at the institutional as well as the popular level in Brazil is similar to that in North America (U.S. and Canada), Australia, and New Zealand. Menezes de Souza advocates Walter Mignolo's notion of "border thinking" as a means to change "the colonial balance of power in knowledge production" (6). Discussing the relationship between Indigenous knowledge and writing, Menezes de Souza describes the Eurocentric concept whereby "alphabetic knowledge is seen to be the origin of philosophy and justice because it reified and decontextualized speech and facilitated the transformation of knowledge, now written down, into an object of contemplation (and the harbinger of abstract thought)" (10). He considers these assumptions alongside the view commonly espoused by many non-Indigenous organizations that Indigenous languages and cultures need to be enshrined in the Western written tradition for their own protection. Implicit in this view is the contradictory belief that "writing ... is an innocuous, transparent technology and an essential instrument for the preservation and dissemination of Indigenous knowledge" (7). Attempts to read Indigenous writing accordingly deny what Menezes de Souza describes as "the crucial point in defining Indigenous knowledges ... the recognition of their place-based locus of production and use in communities ethnically distinct and socio-historically distant from national centers of political and economic power" (7). Linked with that is the fact that several of the Amazonian cultures with which he is familiar are cultures of vision, where "alphabetic writing which merely registers speech needs to be complemented by the drawing of a visual text to guarantee the registration of knowledge" (9). For the storytellers discussed here, texts are oral/aural and visual/graphic. Simultaneously developing each of these forms is the greatest challenge facing Lorna Little, Michael Kusugak, and Daisy Utemorrah, teamed with their respective illustrators, Janice Lyndon, Vladyana Krykorka, and Pat Torres.

Lorna Little is a Western Australian Nyoongar elder and, as such, the myth story of The Mark of the Wagarl, is hers to tell. Little's claim to the story is established in the opening pages, where photos of both Little and her Nyoongar illustrator, Janice Lyndon, are accompanied by brief biographies. This is followed by a list of Nyoongar words and the explanation that "The Sacred Rainbow Serpent, Maadjit Walken, is the mother spirit and creator of Nyoongar Country, in the southwest of Western Australia. She formed the rivers, swamps and creeks, and all the trees and vegetation. Maadjit Walken made her first child the guardian spirit of the rivers and Fresh waters. His 
name is Maadjit Wagarl, the Sacred Water Snake" (1). Little's explanation is complemented by the opening paragraphs of the myth story itself: "This is a story about the Wagarl ... It is also the story of how a little boy received the Wagarl for his totem" (3). The double spread immediately inside the cover establishes that the story is being "told," not written, as it shows a group of children sitting cross-legged beside a river, listening to two elders. As we later learn, the site itself is central to the story. The same illustration also accompanies the opening paragraph. While the first half of the myth story concerns itself with the significance of the Wagarl for the Nyoongar people, the latter part tells of the disciplining by the Wagarl itself of Baardi, a disbelieving boy who dives into the river and disturbs the sacred snake in its cave. The Wagarl allows him to live on the proviso that he never speaks again and takes special care of all snakes. The story concludes with the explanation, in italics, that Baardi's leg was marked by the Wagarl and the birthmark has been passed down between generations into the present, marking the descendent who is to be "the spiritual brother or sister to the sacred snake" (27). This is followed by another double-spread with the same illustration of the children listening to their elder. Importantly, the listening children are Aboriginal, which serves as a reminder that Indigenous texts - for both children and adults - are generally produced with both an Indigenous and non-Indigenous readership in mind.

For children, whether Aboriginal or non-Aboriginal, The Mark of the Wagarl is a cautionary tale dealing with curiosity and lack of belief. Baardi must suffer the consequences of his actions and unwittingly pronounces his own punishment when he entreats the Wagarl, '"If you let me go, I promise I'll never tell anyone about you"' (20). For adults, however, Little sees the narrative differently. She suggests it is a story about faith and what we do with it, as well as the interaction between discipline and spirituality. Nevertheless, for both adults and children it is a story about the past in the present. The Mark of the Wagarl is, as I have said, a myth story. Ronald Wright offers some indication of the significance of the genre when he observes that "myth is an arrangement of the past, whether real or imagined, in patterns that resonate with a culture's deepest values and aspirations... Myths are so fraught with meaning that we live and die by them. They are the maps by which cultures navigate through time" (Wright qtd. in Wilson 4). Cultures mythologize themselves and others in order to make sense of their world: communicating myth stories between generations and between cultures is important to their continuation. It is also an act of generosity. For storytellers, writers, and illustrators from a particular culture to make a myth accessible to children (and adults) of another culture promotes understanding. However, this is a prospect that can only be fully realised if non-Indigenous adults and children are taught to read in new and different ways. Not surprisingly, many texts written and illustrated by Aboriginal people are cultural and political commentaries. Authors and illustrators experiment with a variety of approaches to their material in an attempt to better represent the worlds of their particular stories, whether based on traditional tales or experiences common to Indigenous and non-Indigenous readers. One of the most striking features of Australian children's literature in the last thirty years has been the emergence of Aboriginal publishing houses and the publication of stories by Aboriginal writers and illustrators, aimed at both an Indigenous and non-Indigenous readership. This political and ideological direction is particularly evident in Western Australia, where Magabala Books in Broome publishes a diverse range of Indigenous literature for children and adults. This is complemented by the Fremantle Arts Centre Press in Perth and the University of Western Australia Press, both of which are committed to Aboriginal cultures and issues. These publishing houses have provided some freedom from the homogenizing influence of many mainstream publishers, enabling the use of different sorts of narrative and discourse. However, children's literature requires (and is distinguished from adult literature by) its own fields of activity in publishing, marketing, reading and criticism. The cultural differences evidenced in much Indigenous children's literature require further variation within these fields of activity. Perhaps the most pressing example of this is in the form of non-Aboriginal adult readings and criticism. In relation to Indigenous literature in general, the Ojibwe writer Kimberly Blaeser has noted the need to find a way "to approach Native Literature from an indigenous cultural context, a way to frame and enact a tribal-centered criticism" (53). She is looking for a critical voice and method which moves from the culturallycentered text outward toward the frontier of 'border' studies, rather than an external critical voice and method which seeks to penetrate, appropriate, colonize or conquer the cultural center, and thereby, change the stories or remake the literary meaning" (53). In other words, academia is presently ill-equipped to do justice to these texts. 
Clare Bradford details the "agendas" of contemporary children's texts by Aboriginal authors as "recovery and retelling of traditional narratives; recovery and deployment of Aboriginal languages, including Aboriginal English; rewriting of historical narratives from the point of view of Indigenous people; narratives featuring the experience of Aboriginal people in urban settings; engagement with contemporary cultural and political questions; production of hybrid texts incorporating indigenous and non-indigenous traditions; new forms of collaboration between Aboriginal and nonAboriginal people" ("Place and Politics" 4). The works of Utemorrah, Little, and Kusugak address all of these issues and thus they show that the most effective picture books function by making use of the gaps between words and pictures. Each picture book is really three texts: pictures, words, and a combination of both. Most often, it is the pictures which invite viewers to respond to the story, much of the meaning of which is made by pictorial dynamic. Illustrations are a key source of information about the story through use of shape, style, composition and size. Readers are invited to respond in different ways with the use and size of borders, the size and type of print, and placement of pictures and words in relation to each other. Mood is usually conveyed through use of color and shape, both of which influence a reader's response (see Nodelman and Reimer 280). These elements are all particularly useful in the literary space. Whether consciously or not, illustrators (like writers) work in culturally specific styles and readers have certain basic in-built expectations of illustrations; for example, viewers who read a language such as English or French, moving left to right, also "read" pictures left to right. Likewise, for them, the glance curve runs from [the] lower left corner to [the] upper right corner. Predictably, these readers read time left to right, as action on the left occurs before what happens on the right (Nodelman and Reimer 290). An appreciation of such fundamental characteristics of picture books suggests that the most effective of them are complex art forms which can be informative, enjoyable and encourage critical thinking in adults and children alike. Lewis elaborates on this when he describes the picture book genre as "always developing and open-ended", containing "words and images rubbing shoulders ... different kinds of words, even in some instances different kinds of images" (142).

Children's literature and Indigenous literature have often been compared by scholars and critics for the wrong reasons. It is true that "just as colonizing countries have adopted a paternalistic stance towards the 'natives' and a patronizing one to their writings so, within what seems to be a single culture, the same attitude has been taken to children's books" (Hunt, Literature 2). It is also true that deceptive simplicity of an intrinsically complex process often characterizes both oral tradition and children's literature, making the two areas difficult to adequately define, particularly for a general readership. Not surprisingly, Western acknowledgement of the power and complexity of either oral tradition or children's literature has been slow in coming. However, while this comparison should end here, it often does not. Maria Nikolajeva, for example, has postulated an evolutionary model for children's literature, applicable, she argues, to all countries and languages, where the most "sophisticated" or "literary" texts are seen as the most developed (95). Certainly, children's literature in general is becoming increasingly elaborate. But it must be remembered that there exist simultaneously a variety of deceptively simple, effective forms and this fact challenges Nikolajeva's model. The complex literary space of Indigenous children's picture books is foremost among these, since it has been shown that both oral and written traditions are rich and complex forms of communication, engaging listeners and/or readers in specific yet quite different ways.

In Native Americans in Children's Literature Stott notes of Indigenous storytelling that original audiences would have watched the facial expressions and gestures of the tellers and would have been able to imagine the settings, animals, dwellings, costumes, and designs depicted in the stories (24). Obviously, this is impossible for most modern children, who need pictures to make important details visible and effectively replace the voice and gestures of the teller. The same is true of many adults. It thus becomes clear that picture books must be culturally accurate; great attention must be paid to detail and the originating culture of a story must be acknowledged. In the context of children's picture books in the English-speaking world at least, Indigenous picture books refuse "to take for granted how stories should be told and thus implicitly [comment] upon the nature of fiction itself" (Lewis 132). As is seen in the works of Little, Kusugak, and Utemorrah, some information on the writer and illustrator is useful - particularly for the adult reader, who can often also discern the reasons for the telling of the story and publication of the book. In the case of nonIndigenous storytellers of traditional Indigenous stories, Stott also suggests that "an awareness of differences between the retelling and its sources - additions, deletions, expansions, alterations helps readers better understand the meanings and intentions of the adaptors" (24). At this point, 
the question is usually raised as to who has the ability and the right to tell stories - whether traditional or contemporary - of another culture (on this, see, e.g., Braz)? While this fraught issue is beyond the scope of the present discussion, it is worth noting that central to this debate is whether individuals of one culture can adequately represent the knowledge, spirituality and experiences of another culture. As the Abenaki storyteller and writer Joseph Bruchac has said: "deep knowledge is necessary for anyone (Native or non-Native) to write well about those essential building blocks of Native American cultures - the words of their elders, the traditional stories told to their children" (Bruchac qtd. in Stott xiii). Bruchac argues that story-telling, whether by or about a given culture group, is a powerful medium. This assumes an informed and accurate writer. In the hands of such writers (whether Indigenous or not) and of critical readers, the picture book blossoms into a unique artistic and educational opportunity.

The Inuk storyteller and writer Michael Kusugak's My Arctic 1,2,3 (1996) is in many ways similar. Like The Mark of the Wagarl, it is culturally specific. Although elements such as family interaction are common to most children, both texts remain "exotic": Inuit appearance and dress are as novel to many children in southern hemisphere countries, such as Australia, as polar bears in a snow-covered landscape. My Arctic aims to educate in two important ways: to teach Indigenous and non-Indigenous children to count, and to introduce non-Indigenous children to Inuit culture and lifestyle in Nunavut. It is actually two books in one. The counting book features full-color illustrations, by Vladyana Krykorka, of Arctic animals in a hunter-prey relationship. Kusugak introduces number concepts through the seasonal cycle, ranging from one polar bear "walk[ing] along the huge floe edge on Hudson Bay" to one million berries that "ripen in the fall," before returning to "one lone polar bear" searching for food in an autumnal landscape. The body of this text is framed by Kusugak's own story; following the title page and the dedications is a section in which Kusugak describes in simple terms some of the aspects of his Inuit lifestyle, such as where he grew up, the clothes he wears and his favorite foods. Beneath this is a color sketch of Kusugak and two Inuit children. The whole is offered with a conversational oral quality. The reader returns to Kusugak's experiences in the final five pages of the book, when he writes of the life he and his family live in Rankin Inlet with the animals of the tundra and the polar sea. A short paragraph elaborates on each of the animals referred to in the body of the counting text and is accompanied by a small black and white sketch. There is also a glossary of northern terms at the end of the book, ensuring that it is a multi-layered learning experience. A further instance is found in Kusugak's inclusion of inuksugak, which appear intermittently in his work. He explains that, while they were originally built of huge rocks in the form of a large man to aid in the corral of caribou, they are now used as landmarks "to help people find their way home". This combination of written and oral traditions, skillfully integrating illustrations, may engage an adult reader as well as a child. If, as O'Sullivan asserts, "'children's literature' denotes a simultaneous co-existence of a plurality of textual manifestations" (27), then this could be an example of the fulfilment of the genre's potential.

Inscribing difference while providing the young reader/listener with some familiar elements is one of Kusugak's strengths. Another of his picture books, Northern Lights: The Soccer Trails, exemplifies this, focusing on the surprising combination of family relationships, death, immortality, and soccer. It tells the story of a young Inuk girl, Kataujaq, and her loving relationship with her mother. When "one day, a big sickness [comes]" and her mother is "sent away, way down south in an aeroplane ... she never [comes] home again ... Her mother just never [comes] home again" (8). As the story proceeds, Kataujaq learns to play soccer with the other children with a soccer ball made of caribou skin stuffed with dry moss and fur. They play in the moonlight on the sea ice with goals made of ice blocks, and "they would run for miles and miles all night long" (10). Yet Kataujaq continues to feel sad and lonely. At this point in the story the northern lights (aurora borealis) are introduced, beautifully illustrated by Krykorka: "They are thin strands of light, thousands of thin strands of light, that move about from here to there like thousands of people running around, following one another" (12). Standing on the ice surrounded by the northern lights Kataujaq's grandmother explains death:

People die ... And, when they die, their souls leave their bodies and go up into the heavens, and there they live. The thousands of people who have passed before us all live up there in the sky. When they were on earth, they too liked to play soccer. You can see them, thousands of them, all running around chasing their soccer ball all over the sky ... But unlike us, they are immortal now and nothing hurts them anymore, so they use a huge, frozen walrus head with big tusks for a soccer ball. When they give that walrus head a mighty kick, it flies across the sky, and they all chase it from one corner of the sky to the other. If you whistle, they will come 
closer, and, if you keep whistling, they will come even closer. But, beware, they may come too near. If they do, that walrus head might come swooping down and "Bonk!" knock your head off. When they come too close, rub your fingernails together so they make a clicking sound. That will make them go away. (12-14)

She proceeds to explain that Kataujaq's mother and grandfather are up there. The little girl watches the northern lights and finally sees her mother. The story concludes with the teller directly addressing the reading/listening child, reiterating that the northern lights "really are the souls of people who have died... And if you look closely, maybe you will see someone special whom you thought had gone away forever. That special person has not really gone away at all. It is the most wonderful thing. Taima" (18). As mentioned previously, Krykorka's illustrations are stunning, capturing the seasonal colours and beauty of the landscape, as well as depicting in minute, accurate detail the appearance, clothes, toys and activities of the Inuit (Kusugak insisted before they began their collaboration that she spend time in his community and meet the children upon whom his characters are based).

In an Australian context Daisy Utemorrah and Pat Torres's Do Not Go around the Edges (1990) also provides a multi-faceted learning experience with an obvious influence of oral tradition. As Bradford has noted, "The strategies of meaning-making deployed in Do Not Go Around the Edges demonstrate conceptual and textual complexities far removed from any simplistic notion of a mixture or blending of elements from different cultures. Rather its multiplicity of narratives and systems of meaning destabilizes the domination of British culture and standard English, forcing readers into new modes of reading" (Unsettling Narratives 68). Indeed it does and it challenges the boundaries of children's literature as propagated by most Western scholars, critics, and readers. However, contrary to Karen Patricia Smith, I suggest that, while the text is marketed as children's literature and won the Australian Multicultural Children's Book of the Year Award in 1991, Utemorrah and Torres offer it simultaneously to children and adults, Aboriginal and non-Aboriginal. Do Not Go around the Edges is strongly autobiographical. Both Utemorrah and Torres are traditional storytellers, which is evident in the way that Torres's illustrations do not simply echo Utemorrah's story, but add a dimension of their own. Each double-page spread contains three distinct threads and the process of interweaving them creates the text. Utemorrah's autobiography sits at the bottom of the page outside a border. Above this is a second border which surrounds Torres's vibrant art-work. Utemorrah's poems are situated within this space, contained by yet another border. The book opens with a photograph of Utemorrah's face as she gazes into the distance. This photograph merges with a map of the Kimberley region in north-western Australia, focusing on the island of Galinji, where Utemorrah was born, as well as Kunmunya Mission, where she grew up, and Mowanjum, where she lives now.

In Do Not Go around the Edges ideology and discourse are inseparable, together creating a sense of self and landscape. As the title suggests, Australians should not be afraid of this process and metaphorically cling to the continent's edges, but should venture physically, emotionally, and spiritually into the centre, clearly identified in this text with Aboriginal Australia. The first poem reads: "Do not go around the edges / Or else you'll fall. / No good that place / Or else you slip" (1). This sentiment is embedded in a brilliant ochre colored illustration of a group of Wandjina spirits around a fire. Beneath the illustration and separated from it by a border, the autobiography begins: "Story About My Life. I was born in Kunmunya Mission in February 1922. From my childhood I lived with my parents, in a humpy" (1). This pattern is repeated throughout the text, to the point that the facts of Utemorrah's autobiography are overshadowed by an impressive mix of dreaming stories, experiences and opinions within the context of Torres's vibrant illustrations. The privileging of the communal over the personal is characteristic of an oral tradition. These illustrations combine traditional Aboriginal art-work with realistic depictions of flora, fauna and human figures. In this context, Utemorrah and Torres reveal aspects of the Dreaming: a difficult concept to which English language is profoundly ill-suited. It may roughly be described as pertaining to Aboriginal philosophical and religious tradition (McGrath 377). Utemorrah's poems "Burun Burun the Kingfisher" (7) and "Wandjinas" (16) elaborate on this and thus are educational. At the bottom of the double-page spread which contains the latter, Utemorrah notes in her autobiography: "This is what they told me: the Wandjina is our God, he's the one which gave us everything, the land, our country, our dreamtime stories, that's what my parents told me" (16). On this spread the reader's attention is drawn firstly to the art work - a stunning ochre colored drawing of Wandjinas - and the poem inside it. Both of these represent a communal experience, before the reader's eyes drift down the page to Utemorrah's simple autobiographical comment. This movement from 
the communal to the personal, prompted by the convergence of art-work, poem and autobiography, exemplifies the way that Do Not Go around the Edges fosters diverse meaning-making processes.

The idea of language is as important to the text as the use of language. Utemorrah states that she speaks three Aboriginal languages: Ngarinyin, Wunambal, and Worrora, stressing that "I help with the language to make it live again" (28). Interestingly, beyond the use of language groups and some animals, Aboriginal languages are not actually incorporated into the story, which is told in a mixture of Standard English and Aboriginal English. Similarly, an emphasis on the relationship between language and experience is central to Story about Feeling (1989), by Western Australian Bunitj Clan elder Bill Neidjie, also published by Magabala Books. This text is a selected series of transcriptions, organized by Keith Taylor, concerned primarily with sharing part of Neidjie's Dreaming. It is arranged on the page in a series of verse-like structures, and includes maps and illustrations of Aboriginal artwork. Neidjie is generously sharing aspects of his culture with nonAboriginal readers and listeners. He begins: "Tree, grass, star ... / because tree and star working with you. / We got blood pressure / but same thing ... spirit on your body, / but e working with you. Even nice wind e blow ... having a sleep ... / because that spirit e with you" (2). And he concludes the final section, entitled "We Like White-Man All Right," forcefully: "No-matter about that White-European, / e can go with that one but must White-European got to be listen this culture / and this story / because important one this. / This on my Bunitj Clan I put it" (171). While Neidjie's Aboriginal English differs notably from Utemorrah's hybrid English, both are storying their culture and themselves in the literary space created when oral and written traditions meet. It is not surprising then that the fifteen poems in Do Not Go around the Edges vary in complexity and length. In "Bind with the White Man's Law" the reader overhears a conversation between the Mother Land and the poet, during which the former laments: "Come back, why have you left me alone? / The white man's law still binds you. / The time will come when you must pass - / I am lost without you, thinking of the times, / the days when you were here, / so proud in your Mother Land" (11).

As the text proceeds, the mood darkens noticeably and some of the sentiments expressed are reminiscent of Neidjie's darker moments. However, while Neidjie remains determined that nonAborigines will have to listen and learn, Do Not Go around the Edges culminates in "Our Mother Land":

Our dream and our past is buried under the ground.

When the sun rises and begins another day

all is empty, ground and hill shake on us,

overwhelmed with people everywhere.

The dream the past - where does it stand now?

The burun burun whirrs in the night time

And the owl calling!

And the dingo howling!

The moon shines on the water, all is ended -

And the dreamtime gone. (29)

Torres's corresponding double-page illustration is a mix of swirling grey-blue brush strokes, at the centre top of which is a moon. A trail of bright yellow and red horizontal brush strokes diminishes in length and vibrancy as the reader's gaze is drawn from the bottom of the illustration towards the pale top. Outside the border, at the very bottom of the last page is Utemorrah's final, impressive statement, reflecting the mood of the poem and illustration: "And now I am getting old." Do Not Go around the Edges, like Neidjie's Story about Feeling, is no fairytale adapted for nonAboriginal children. It is instead a combination of Dreaming stories, communal experiences and opinions and personalized political commentary on non-Aboriginal Australia's shameful treatment of the continent's First Nations. Simultaneously, it is a celebration of traditional Aboriginal culture and a veiled warning of the consequences of interfering with it. Finally, it is a lament for damage already done. The finely interwoven poems, illustrations and autobiography speak powerfully and in different ways to readers of any age.

The characteristics of Indigenous children's literature are well-suited to communicating the complexities of one people's culture and history to another. The fact that the children's picture book aims at - but is most definitely not restricted to - a child readership without necessarily 
detracting from complex cultural content further evidences its potential in the hands of adult readers who are prepared to learn to read in new and different ways. Indigenous writers have of course produced works fitting into all literary categories as well as works that challenge categorization. The works of Michael Kusugak and illustrator Vladyana Krykorka, for example, range from My Arctic 1,2,3 to Northern Lights: The Soccer Trails, the latter of which is a myth-story, autobiography, and a story about contemporary Inuit culture. In this respect, it is similar to Daisy Utemorrah and Pat Torres's Do Not Go around the Edges and Lorna Little's The Mark of the Wagarl. Each of these texts is a meeting place for oral and written traditions featuring intricate patterning of words and illustrations, which tell their own complementary stories. In accordance with the oral tradition, the texts discussed speak to both adults and children, Indigenous and nonIndigenous readers. To children, they may be simplified myth-stories and stories of specific Indigenous peoples. To more advanced readers, the texts speak differently, as the written word is combined with illustrations, maps and additional information such as the author's and illustrator's background. Of course, the adult readers' life experiences and education exert a significant influence on the way meanings are made: the texts will obviously be perceived differently by a member of the same language group as the writer or a different language group or a non-Indigenous person. It is a shame when these rich texts are dismissed, according to the tenets of Western children's literature, as at best valuable for children alone and at worst devoid of value. Often this dismissal is taken one step further and Indigenous literature in general, and myth-stories in particular, is infantilized. A comparative methodology allows an investigation into and rejection of this occurrence. In fact, utilizing a comparative methodology in the study of what I have termed Indigenous children's picture books illuminates an important literary space. As Hans Ulrich Gumbrecht has said, rather than actually comparing literatures, "comparative literature" now names "an intellectual and institutional space ... where experimental thinking relevant for the future of the Humanities [can] take place" (Gumbrecht qtd. in O'Sullivan 5). It is this space which affords the opportunity to consider the exciting prospects of Indigenous children's picture books.

\section{Works Cited}

Blaeser, Kimberly. "Native Literature: Seeking a Critical Center." Looking at the Words of Our People: First Nations Analysis of Literature. Ed. Jeannette Armstrong. Penticton: Theytus, 1993. 51-62.

Blažić, Milena Mileva. "Children's Literature in South-East Europe." CLCWeb: Comparative Literature and Culture 13.1 (2011): <http://docs.lib.purdue.edu/clcweb/vol13/iss1/10>.

Bradford, Clare. "Place and Politics: Aboriginal Texts for Children." Viewpoint 10 (Summer 2002): 3-6.

Bradford, Clare. Reading Race: Aboriginality in Australian Children's Literature. Carlton South: Melbourne UP, 2001.

Bradford, Clare. Unsettling Narratives: Postcolonial Readings of Children's Literature. Waterloo: Wilfrid Laurier UP, 2007.

Braz, Albert. "Collaborative Authorship and Indigenous Literatures." CLCWeb: Comparative Literature and Culture 13.2 (2011): <http://docs.lib.purdue.edu/clcweb/vol13/iss2/3>.

Cruikshank, Julie. Life Lived like a Story: Life Stories of Three Yukon Native Elders. Lincoln: $\mathrm{U}$ of Nebraska $\mathrm{P}$, 1990.

Damm, Kateri. "Says Who: Colonialism, Identity and Defining Indigenous Literature." Looking at the Words of Our People: First Nations Analysis of Literature. Ed. Jeannette Armstrong. Penticton: Theytus, 1993. 1026.

Harjo, Joy, and Gloria Bird, eds. Reinventing the Enemy's Language: Contemporary Native Women's Writings of North America. New York: Norton, 1997.

Hunt, Peter. An Introduction to Children's Literature. Oxford: Oxford UP, 1994.

Hunt, Peter. Introduction. Literature for Children: Contemporary Criticism. Ed. Peter Hunt. London: Routledge, 1992.

King, C. Richard, and John Streamas, eds. Racialized Narratives for Children. Thematic issue CLCWeb: Comparative Literature and Culture 10.2 (2008): <http://docs.lib.purdue.edu/clcweb/vol10/iss2/>.

Kusugak, Michael, and Vladyana Krykorka. My Arctic 1,2,3. 1996. Toronto: Annick, 2001.

Kusugak, Michael, and Vladyana Krykorka. Northern Lights: The Soccer Trails. 1993. Toronto: Annick, 2003.

Lewis, David. "The Constructedness of Texts: Picture Books and the Metafictive." Signal 62 (May 1990): 13146.

Little, Lorna, and Janice Lyndon. The Mark of the Wagarl. Broome: Magabala, 2004.

McCormack, Patricia. "Competing Narratives: Barriers between Indigenous Peoples and the Canadian State." Indigenous Peoples and the Modern State. Ed. Duane Champagne, Karen Jo Torjesen, and Susan Steiner. Walnut Creek: AltaMira, 2005. 109-20.

Menezes de Souza, Lynn Mario Trinidade. "Remapping Writing: Indigenous Writing and Cultural Conflict in Brazil." English Studies in Canada 30.3 (2004): 4-16.

McGrath, Ann. "Contested ground: what is 'Aboriginal history'?" Contested Ground: Australian Aborigines under the British Crown. Ed Ann McGrath. St Leonard's: Allen and Unwin, 1995. 359-97. 
Angeline O'Neill, "Aboriginal Australian and Canadian First Nations Children's Literature" page 10 of 10

CLCWeb: Comparative Literature and Culture 13.2 (2011): <http://docs.lib.purdue.edu/clcweb/vol3/iss2/4> Thematic Issue About Indigenous Literature. Ed. Angeline O'Neill and Albert Braz

Moses, Daniel David, and Terry Goldie. "Preface to the First Edition: Two Voices." An Anthology of Canadian Native Literature. Ed. Daniel David Moses and Terry Goldie. Oxford: Oxford UP, 2005. xiii-xxii.

Neidjie, Bill. Story about Feeling. Broome: Magabala, 1989.

Nikolajeva, Maria. Children's Literature Comes of Age: Towards a New Aesthetic. New York: Garland, 1996.

Nodelman, Perry, and Mavis Reimer. The Pleasures of Children's Literature. Boston: Allyn and Bacon, 2003.

O'Sullivan, Emer. Comparative Children's Literature. Trans. Anthea Bell. London: Routledge, 2005.

Smith, Karen Patricia. "Landscapes of the Heart; Sharings of the Soul: Illustrated Universes in Australian Aboriginal Picture Books of the 1990s." Bookbird 37.1 (1999): 19-24.

Stott, Jon. Native Americans in Children's Literature. Phoenix: Oryx, 1995.

Utemorrah, Daisy, and Pat Torres. Do Not Go Around the Edges. 1990. Broome: Magabala, 1992.

Wilson, James. The Earth Shall Weep: A History of Native America. New York: Grove, 1998.

Wolf, Doris, and Paul DePasquale. "Home and Native Land: A Study of Canadian Aboriginal Picture Books by Aboriginal Authors." Discourses of Children's Literature in Canada. Ed. Mavis Reimer. Waterloo: Wilfred Laurier UP, 2008. 68-87.

Author's profile: Compiler's profile: Angeline O'Neill teaches English literature at The University of Notre Dame Australia. Her interests in research include comparative Indigenous literatures, children's literature, Australian literature, and literary theory. O'Neill's recent publications include "Creating a New Space: From Literary Migrants to Resistance Writers," Comparing Migration: The Literatures of Canada and Québec (Ed. Catherine Khordoc and Marie Carrière, 2008) and "Anthologizing Indigenous Literature," On Anthologies: The Politics and Pedagogy of Anthologizing (Ed. Jefrrey Di Leo), Special Issue symploke: A Journal for the Intermingling of Literary, Cultural and Theoretical scholarship (2004), and she has co-edited, with Anne Brewster and Rosemary Van den Berg, Those Who Remain Will Always Remember: An Anthology of Aboriginal Writing (2000). Email: <angeline.oneill@nd.edu.au> 